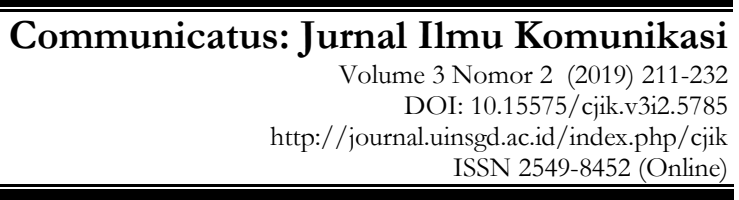

\title{
Pemaknaan Perempuan Kepala Keluarga terhadap Pesan-Pesan pada Radio Komunitas Pekka FM
}

\author{
Chairiawaty $^{1 *}$ \\ ${ }^{1}$ Universitas Islam Bandung \\ *email:Chairiawaty@gmail.com
}

\begin{abstract}
The purpose of the study was to obtain a picture of the female head of household in interpreting messages on the Pekea FM Community Radio in Batumulik. Village, Lombok, including; knowledge of broadcasts on Pekek FM radio, the most popular radio broadcasts, benefits and changes that occur to female household heads after listening to Pekka FM radio broadcasts. Research using the phenomenological method. Data collection is done through observation, interviews, and documentation. The results showed that female heads of households knew and knew Pekea FM Radio as a radio that conveyed messages and provided knowledge about various things, the most preferred radio broadcasts by informants were about women's reproduction, adolescent health, family planning, pregnancy, news about Pekka, entertainment and advertising. The changes felt by women household heads after listening to messages on Pekka FM Radio are that they can change the mindset and mentality of women household heads, so that they become confident, diligently care for the body, and dare to speak. Broadcast programs that provide significant change can answer the needs of the audience.
\end{abstract}

Keywords: Female Headed Household, Community Radio, pek.ka FM

\section{ABSTRAK}

Tujuan penelitian adalah untuk memperoleh gambaran mengenai Perempuan Kepala Keluarga dalam memaknai pesan-pesan pada Radio Komunitas Pekka FM di Dusun Batumulik Lombok, meliputi; pengetahuan terhadap siaran-siaran di radio Pekka FM, siaran radio yang paling diminati, manfaat dan perubahan yang terjadi pada perempuan kepala keluarga setelah mendengarkan siaran-siaran radio Pekka FM. Penelitian menggunakan metode fenomenologi. Pengumpulan data dilakukan dengan observasi, wawancara dan dokumentasi. Hasil penelitian menunjukkan bahwa, para perempuan kepala keluarga mengenal dan mengetahui Radio Pekka FM sebagai radio yang menyampaikan pesan-pesan dan memberikan pengetahuan mengenai berbagai hal, siaran radio yang paling disukai oleh para informan adalah mengenai reproduksi wanita, kesehatan remaja, KB, kehamilan, berita seputar Pekka, hiburan dan iklan. Perubahan yang dirasakan oleh para perempuan kepala keluarga setelah mendengarkan pesan-pesan pada Radio Pekka FM adalah, dapat mengubah pola pikir dan mental para perempuan kepala keluarga, sehingga menjadi percaya diri, rajin merawat tubuh, dan berani berbicara. Program-program siaran yang memberikan perubahan signifikan adalah yang mampu menjawab kebutuhan khalayak.

Kata kunci : Perempuan kepala keluarga, radio komunitas, pekka FM

Diterima: Agustus 2019. Disetujui: Oktober 2019. Dipublikasikan: Desember 2019 


\section{PENDAHULUAN}

Perempuan Kepala Keluarga yang merupakan kelompok perempuan berusia antara 20 sampai 60 tahun, lebih dari 38.8 persen buta huruf dan tidak pernah duduk di bangku sekolah dasar sekalipun, menghidupi antara satu sampai enam orang tanggungan, bekerja sebagai buruh tani dan sektor informal dengan pendapatan rata-rata kurang dari Rp 10.000 per hari (Susanti, 2015). Lahir dari kepedulian para pekerja sosial (orang yang didasari oleh pengetahuan, keterampilan dan nilai dalam melakukan intervensi sosial terhadap permasalahan sosial, terutama pada wanita yang melihat begitu banyak wanita yang menjadi kepala keluarga, baik dikarenakan ditinggal mati oleh suaminya, karena bercerai dan atau diceraikan dari/oleh suaminya, atau bisa jadi wanita menjadi kepala keluarga dimana masing-masing hanya ada satu kepala rumah tangga yang melegitimasi kekuatan kepala dirumah tangga dan pengaruh kepala rumah tangga terhadap pengambilan keputusan yang biasanya sangat kuat (Yang, S., Fan, Y., Deng, W., \& Cheng, L. (2017). Karena suaminya tidak mampu lagi mencari nafkah dengan alasan kesehatan atau kondisi fisik yang sudah renta, sehingga mengharuskan dia menggantikan tanggung jawab mencari nafkah di pundaknya, dan para wanita yang masih lajang akan tetapi menjadi tulang punggung keluarganya. Data BPS 2018 menunjukkan bahwa jumlah rumah tangga yang dikepalai perempuan di Nusa Tenggara Barat mencapai 22,52\% atau sekitar 5.15 juta dari jumlah rumah. Jika dibandingkan data tahun 2007 ketika Pekka pertama digagas pada tahun 2007 yang kurang dari 13\%, data ini menunjukkan kecenderungan peningkatan rumah tangga yang dikepalai perempuan naik ratarata $0.1 \%$ per tahun.

Kondisi perempuan kepala keluarga di Nusa Tenggara Barat ini sangat memprihatinkan. Mata pencaharian mereka mayoritas adalah buruh tani, pedagang sayuran (hanya beberapa jenis sayuran saja, misalnya jagung atau tauge, bawang merah yang mereka beli dari pasar induk pada dini hari) yang rata-rata pendapatan maksimal mereka perhari adalah Rp. 30.000, sedangkan mereka harus menanggung 4-6 orang dalam satu rumah. Pendidikan mereka sangat rendah, ratarata tidak pernah sekolah, sehingga mereka buta aksara dan tidak bisa berhitung. Sedangkan anggota luar biasa Pekka, yaitu yang memiliki suami, pekerjaan suaminya rata-rata adalah penunggang Cidomo (dokar), atau buruh tani, yang penghasilannya juga sangat jauh dari layak. Ligkungan tempat tinggal mereka bisa dikatakan sangat kumuh, dengan kondisi rumah semi permanen, lantai masih dari tanah, antara atap satu rumah degan rumah lainnya saling menempel, tidak ada "jamban" sehingga kegiatan mandi, mencuci dan lain sebagainya dilakukan di sungai yang airnya pun tidak jernih yang sekaligus juga mereka gunakan untuk memandikan kuda-kuda mereka. Kondisi ini hampir merata di seluruh desa di Kecamatan Gerung, Lombok Barat. Keradaan Serikat Pekka menjadi sebuah alternatif bagi program pemberdayaan yang merupakan suatu proses untuk 
membantu masyarakat memperoleh daya (kuasa) untuk mengambil keputusan dan menentukan tindakan yang akan ia lakukan, termasuk mengurangi efek hambatan pribadi dan sosial dalam melakukan tindakan. Suatu pemberdayaan tentunya memiliki tujuan yang akan dicapai (Saugi \& Sumarno, 2015) terutama bagi para perempuan kepala keluarga ini.

Program-program Pekka FM didesain dari Pekka Nasional, dan disosialisasikan sampai ke tingkat daerah. Pekka pusat mengembangkan media komunikasi yang efektif dan sesuai dengan kebutuihan dikarenakan tidak ada satu media pun yang dapat dianggap sebagai yang terbaik dalam komunikasi, sehingga perlu dipromosikan media komunikasi yang efektif untuk meningkatkan luaran (Moyo \& Salawu, 2019). Di tingkat nasional, media komunikasi difokuskan pada kegiatan dokumentasi dan publikasi yang dititikberatkan pada pembuatan video, foto dan buku terkait dengan kegiatan Pekka dan pengalaman personal para Perempuan Kepala Keluarga, sehingga di tingkat daerah dikembangkan radio komunitas tersebut.

Radio komunitas merupakan media komunikasi baru dalam komunitas yang bersifat interaktif, sederhana, dan memiliki kekhasan, di mana prosesnya berada di antara komunikasi melalui media massa dan komunikasi antarpersona. Karakteristik radio komunitas cenderung merepresentasikan kepentingan berbagai kelompok dalam komunitas dan merupakan wujud resistensi terhadap dominasi informasi penyiaran komersial yang sudah ada selama ini. Peran dan fungsi radio komunitas di pedesaan belum optimal sebagai media percepatan dan perluasan informasi antar warga serta dalam meningkatkan intensitas komunikasi interaktif secara kolektif karena dipengaruhi oleh tradisi-tradisi komunikasi yang sudah mapan dalam bentuk informal, lebih bersifat topdown untuk wilayah tertutup dan bersifat horisontal untuk wilayah terbuka (Rachmiatie, 2005). Radio Komunitas merupakan media pemberdayaan masyarakat, yang bertujuan untuk pendidikan dan peningkatan kapasitas masyarakat.

Radio komunitas merupakan salah satu penyelenggara penyiaran yang ada di Indonesia yang didirikan oleh komunitas dalam rangka memenuhi kebutuhan komunitas. Radio Komunitas memiliki karakteristik independen, dan tidak komersial, dengan daya pancar rendah, luas jangkauan wilayah terbatas, serta untuk melayani kepentingan komunitasnya (Budiman, 2002). Istilah lain adalah sebagai media partisipatif yang merupakan alat komunikasi yang berguna untuk menghubungkan orang dengan yang umum (Sujata, Khor, Ramayah, \& Teoh, 2019) yang mensyaratkan keterlibatan komunitas di dalamnya. Semakin banyak keterlibatan warga dalam lembaga penyiaran komunitas, mendorong adanya keberagaman isi siaran yang semakin baik. Pendirian Radio Komunitas dipandang sangat penting dalam program PEKKA di daerah, terutama dalam membuka akses bagi para kaum perempuan untuk bisa berpartisipasi dan menggalang persatuan di antara para perempuan kepala keluarga. 
Berdasar fenomena yang diuraikan di atas, sangat signifikan untuk dilakukan studi mendalam tentang,"Bagaimana Para Perempuan Kepala Keluarga di Dusun Batu Mulik Memaknai Pesan-pesan dari Radio Pekka FM?”. Permasalahan dapat diidentifikasi sebagai berikut: (1) Bagaimana pengetahuan para Perempuan Kepala Keluarga tentang Radio Pekka FM?; (2) Siaran Radio Komunitas Pekka FM apa sajakah yang diminati oleh para perempuan kepala keluarga?; (3) Sejauh mana manfaat dari Radio Pekka FM bagi para Perempuan Kepala Keluarga di dusun Batu Mulik?' dan (4) Bagaimana perubahan yang terjadi pada para Perempuan Kepala Keluarga di Dusun Batu Mulik?. Sesuai dengan identifikasi maslaah maka tujuan penelitian ini adalah: (1) Mengetahui bagaimana pengetahuan para Perempuan Kepala Keluarga tentang Radio Pekka FM, (2) Memperoleh gambaran tentang siaran Radio Komunitas Pekka FM apa sajayang diminati oleh para perempuan kepala keluarga, (3) Mengetahui sejauh mana manfaat dari Radio Pekka FM bagi para Perempuan Kepala Keluarga di dusun Batu Mulik., dan (4) Mengetahui bagaimana perubahan yang terjadi pada para Perempuan Kepala Keluarga di Dusun Batu Mulik

\section{HASIL DAN PEMBAHASAN}

Kondisi perempuan kepala keluarga di Dusun Batu Mulik, Nusa Tenggara Barat (NTB) ini sangat memprihatinkan. Rata-rata pencahariannya adalah buruh tani, pedagang satu jenis sayuran seperti tauge atau bawang merah yang pendapatan rata-ratanya perhari adalah Rp. 30.000. Dengan pendapatan yang sangat minim, mereka harus menghidupi 4-6 anggota keluarga. Dari segi pendidikan sangat rendah, bahkan tidak pernah mengenyam pendidikan, sehingga mereka buta aksara dan tidak bisa baca tulis dan menghitung.

Radio komunitas Pekka FM di Kabupaten Lombok Barat merupakan Radio berbasis komunitas (community based) yang dibangun berdasarkan partispasi perwakilan komunitas perempuan kepala keluarga. Program-progran siaran yang ditayangkan dirancang berdasarkan pada kebutuhan lokal komunitas, musik lokal, dialog tentang masalah-masalah seputar perempuan, begitupun berita-beritanya utamanya adalah tentang perempuan. Radio komunitas Pekka FM, selain menjadi pusat informasi dan edukasi bagi komunitasnya, juga dapat menjadi sarana komunitas Perempuan Kepala Keluarga dalam membangun keyakinan diri, memperkuat nilai, dan perubahan pola-pola prilaku dan kekuatan kolektifnya.

Karakteristik khas yang tidak ditemukan pada penyiaran nonkomunitas, Radio Komunitas menjadi sebuah sarana komunikasi yang cukup signifikan bagi komunitas Pekka FM, bahkan radio ini banyak memberikan pengetahuan yang bersifat mendidik, sesuai dengan kondisi dan kebutuhan khalayaknya. Pertimbangannya bahwa ide awal berasal dari warga komunitas yang memiliki hak dan kebutuhan program yang lebih bermanfaat. Program tersebut adalah program yang mendidik, program yang memberikan kedalaman dan 
keteguhan agama serta budi pekerti, dan program untuk meningkatkan kemandirian dan keberdayaan perempuan. Keterlibatan warga sangat tinggi, sehingga Dewan Penyiaran Komunitas (DPK), bisa mengontrol radio tersebut agar memenuhi kebutuhan dan kepentingan warganya.

Radio Komunitas Pekka FM, terletak di Dusun Batumulik, Desa Mesanggok yang terletak di Kecamatan Gerung, Lombok Barat, tidak jauh dari pusat kota/kabupaten tetapi keadaannya terpencil dan masih belum memiliki prasarana lengkap. Kata "Pekka" sendiri diambil dari singkatan Perempuan Kepala Keluarga dan baru berdiri pada Februari 2008 lalu. Radio Komunitas Pekka FM siaran sekitar 12 jam setiap hari, mulai pukul 08.00 WITA, istirahat pukul 12.00 hingga 16:00 WITA, kemudian siaran dilanjutkan sampai pukul 24.00 WITA. Radio Komunitas Pekka FM berbagi pengetahuan dengan para pendengarnya, terutama kaum perempuan, dan memotivasi mereka untuk terlibat aktif dalam pengambilan-pengambilan keputusan yang menyangkut pembangunan di sekeliling mereka. Program acara dikemas dalam bentuk dialog interaktif, termasuk penyuguhan sandiwara radio dan rubrik-rubrik khusus untuk membahas topik-topik yang berkaitan dengan hak-hak perempuan.

Setiap hari siaran dipandu oleh penyiar-penyiar dari kalangan anggota kelompok Perempuan kepala keluarga setempat. Secara bergiliran, sesuai jadwal yang disepakati secara bersama-bersama. Mereka memanfaatkan medium komunitas ini untuk menggemakan keberadaan perempuan dan perannya dalam meningkatkan kesejahteraan keluarga, baik di bidang hukum, pendidikan, kesehatan, dan peningkatan pendapatan mereka. Para penyiar kadangkala harus bertukar jadwal siaran apabila mendadak harus mengurus kebun, lahan tani atau pekerjaan matapencarian lainnya. Bahasa yang digunakan dalam siaran adalah Bahasa Sasak. Meskipun peralatan siaran sangat sederhana tatapi para perempuan kepala keluarga di Kabupaten Lombok Barat ini sangat bangga dengan memiliki Radio Komunitas Pekka FM.

Keberadaan Radio Komunitas Pekka FM di Dusun Batumulik Kecamatan Gerung sangat berarti bagi para warga sekitar terutama bagi kaum perempuannya. Sejak didirikannya pada tahun 2008, Radio Komunitas Pekka FM mengalami kemajuan yang cukup menggembirakan. Apabila pada awal berdirinya Pekka FM hanya siaran pada sore hari, saat ini Pekka FM telah mengudara selama 20 jam perhari.

Kehadiran radio Pekka FM memberikan pengaruh kuat terhadap perempuan kepala keluarga yang bekerja memenuhi kebutuhan mereka sendiri, termasuk untuk memenuhi kebutuhan keluarganya sendiri. Sehingga radio Pekka FM menjadi sangat berarti bagi perempuan kepala keluarga tersebut. Siaran-siaran yang dipancarkan oleh Radio Pekka FM telah mendapatkan simpati dari hati para pedengarnya, seperti yang diungkapkan oleh para informan yang diwawancara oleh peneliti yang hasilnya dapat dilihat pada tabel berikut: 
Tabel 1. Pemaknaan Tentang Pesan-Pesan Radio Pekka FM

\begin{tabular}{|c|c|c|c|c|c|c|}
\hline \multirow[b]{2}{*}{ No } & \multirow[b]{2}{*}{ Nama } & \multicolumn{3}{|c|}{ Siaran Radio } & \multirow[b]{2}{*}{ Manfaat } & \multirow[b]{2}{*}{ Perubahan } \\
\hline & & $\begin{array}{l}\text { Pengetahuan } \\
\text { zntang Siaran }\end{array}$ & $\begin{array}{r}\text { Frekwensi } \\
\text { endengarkan }\end{array}$ & $\begin{array}{l}\text { Siaran yang } \\
\text { aling disukai }\end{array}$ & & \\
\hline 1 & Sumiati & $\begin{array}{l}\text { kesehatan, } \\
\text { akum, KDRI, } \\
\text { KDP }\end{array}$ & & $\begin{array}{l}\text { kesehatan ( } \\
\text { ibu hamil, } \\
\text { kesehatan } \\
\text { ewanitaan ) }\end{array}$ & $\begin{array}{l}\text { jadi tahu } \\
\text { tentang } \\
\text { esehatan pj } \\
\text { wanita }\end{array}$ & $\begin{array}{c}\text { lebih } \\
\text { menjaga } \\
\text { sehatan tubuh }\end{array}$ \\
\hline 2 & Kartini & $\begin{array}{l}\text { kesehatan, } \\
\text { hukum, dll }\end{array}$ & $\begin{array}{l}\text { kadang- } \\
\text { dang, karena } \\
\text { ya kerja dan } \\
\text { idak ada di } \\
\text { rumah }\end{array}$ & $\begin{array}{l}\text { kesehatan ( } \\
\text { reproduksi } \\
\text { wanita dan } \\
\text { rehamilan) }\end{array}$ & $\begin{array}{l}\text { lebih tahu } \\
\text { tentang } \\
\text { kesehatan }\end{array}$ & $\begin{array}{l}\text { jadi lebih } \\
\text { rcaya diri dan } \\
\text { rpengetahuan } \\
\text { tentang } \\
\text { shamilan dan } \\
\text { ra memelihara } \\
\text { roduksi wanita }\end{array}$ \\
\hline 3 & Suriah & tidak tahu & $\begin{array}{l}\quad \text { kadang- } \\
\text { adang kalau } \\
\text { a pertemuan } \\
\text { ıja baru bisa } \\
\text { dengar. }\end{array}$ & $\begin{array}{l}\text { tidak ada } \\
\text { siaran yang } \\
\text { diminati }\end{array}$ & tidak tahu & tidakada \\
\hline 4 & Rakdah & $\begin{array}{l}\text { tentang } \\
\text { kesehatan }\end{array}$ & Sering & $\begin{array}{l}\text { kesehatan, } \\
\text { emaja dan } \\
\text { nyanyian } \\
\text { daerah, } \\
\text { yanyian pop }\end{array}$ & $\begin{array}{l}\text { banyak } \\
\text { memberi } \\
\text { manfaat }\end{array}$ & $\begin{array}{l}\quad \text { lebih tahu } \\
\text { seputar } \\
\text { kehamilan, } \\
\text { :eehatan, tau } \\
\text { ra melindungi } \\
\text { i dari penyakit }\end{array}$ \\
\hline 5 & Murti Sari & $\begin{array}{l}\text { tidak ada } \\
\text { jawaban }\end{array}$ & $\begin{array}{l}\text { tidak } \\
\text { pernah } \\
\text { nendengar }\end{array}$ & tidak ada & tidak tahu & $\begin{array}{l}\text { tidak ada } \\
\text { jawaban }\end{array}$ \\
\hline 6 & Yanti & $\begin{array}{l}\text { kesehatan, } \\
\text { cara berKB, } \\
\text { kshow dengan } \\
\text { iH,ASSAKAK } \\
\text { I.PL }\end{array}$ & Sering & $\begin{array}{l}\quad \text { iklan, } \\
\text { )RI, KB, info } \\
\text { :aha, simpan } \\
\text { njam, kawin } \\
\text { sawah umur, } \\
\text { B, kesehatan } \\
\text { seproduksi }\end{array}$ & $\begin{array}{l}\text { sangat } \\
\text { manfaat, kita } \\
\text { bisa } \\
\text { ormasikan ke } \\
\text { tggota pada } \\
\text { it pertemuan }\end{array}$ & $\begin{array}{l}\text { informasi } \\
\text { ig didapat bisa } \\
\text { sampaikan ke } \\
\text { syarakat pekka } \\
\text { aupun di luar } \\
\text { pekka }\end{array}$ \\
\hline
\end{tabular}

Sumber: Hasil Penelitian 


\begin{tabular}{|c|c|c|c|c|c|c|}
\hline 7 & Mukmin & $\begin{array}{l}\text { iklan, } \\
\text { anyian, sering } \\
\text { anyian daerah, } \\
\text { kesehatan }\end{array}$ & Sering & $\begin{array}{l}\text { kehamilan, } \\
\text { 3, persalinan }\end{array}$ & $\begin{array}{l}\text { bermanfaat } \\
\text { jadi tau cara } \\
\text { berKB }\end{array}$ & $\begin{array}{l}\quad \text { saya jadi } \\
\text { percaya diri } \\
\text { trena jadi tahu } \\
\text { ıenyampaikan } \\
\text { informasi } \\
\text { remasyarakat } \\
\text { lalui iklan yang } \\
\text { tya dengardari } \\
\text { radio pekka }\end{array}$ \\
\hline 8 & Alemah & $\begin{array}{l}\text { tentang } \\
\text { siarannya }\end{array}$ & $\begin{array}{l}\text { kadang- } \\
\text { kadang }\end{array}$ & $\begin{array}{l}\text { nyanyian } \\
\text { dan iklan }\end{array}$ & $\begin{array}{l}\quad \text { bisa } \\
\text { nengetahui } \\
\text { tentang } \\
\text { kehamilan, } \\
\text { gaimana cara } \\
\text { terawat diri }\end{array}$ & $\begin{array}{c}\text { jadi lebih } \\
\text { percaya diri }\end{array}$ \\
\hline 9 & Asmuni & $\begin{array}{l}\text { berika pekka } \\
\text { lan informasi } \\
\text { lainnya }\end{array}$ & $\begin{array}{l}\text { kadang- } \\
\text { kadang }\end{array}$ & $\begin{array}{l}\text { berita } \\
\text { pekka } \\
\text { kehamilan, } \\
\text { reproduksi } \\
\text { remaja }\end{array}$ & $\begin{array}{l}\text { jadi tahu } \\
\text { entang alat } \\
\text { wanita }\end{array}$ & $\begin{array}{l}\text { jadi lebih } \\
\text { percaya diri }\end{array}$ \\
\hline 10 & Rademah & $\begin{array}{l}\text { iklan } \\
\text { kesehatan } \\
\text { reproduksi, } \\
\text { KDRI }\end{array}$ & $\begin{array}{l}\text { kadang- } \\
\text { kadang }\end{array}$ & $\begin{array}{l}\text { program } \\
\text { KB dan } \\
\text { reproduksi }\end{array}$ & $\begin{array}{l}\text { manfaatnya } \\
\text { i tahutentang } \\
\text { kesehatan, } \\
\text { kebersihan } \\
\text { ingkungan }\end{array}$ & $\begin{array}{l}\text { bisa tau lebih } \\
\text { kesehatan }\end{array}$ \\
\hline 11 & Wiranti & $\begin{array}{r}\text { siarannya, } \\
\text { Iformasi yang } \\
\text { sajikan dalam } \\
\text { bentuk iklan }\end{array}$ & Sering & $\begin{array}{l}\text { kesehatan } \\
\text { remaja, } \\
\text { hamilan dan } \\
\text { reproduksi } \\
\text { remaja }\end{array}$ & $\begin{array}{l}\text { jadi lebih } \\
\text { pengetahuan } \\
\text { tentang } \\
\text { zewanitaan }\end{array}$ & \\
\hline
\end{tabular}

Sumber: hasil penelitian

Pemaknaan para perempuan kepala keluarga di Kabupaten Lombok Barat terhadap pesan-pesan yang disiarkan oleh Radio Komunitas Pekka FM seperti yang digambarkan dalam table di atas merupakan hasil wawancara peneliti terhadap 11 orang perempuan kepala keluarga yang ada juga beberapa orang lainnya sebagai significant others.

Pemaknaan perempuan kepala keluarga tentang pesan-pesan pemberdayaan di Radio Pekka FM, meliputi tentang: (1) pengetahuan perempuan kepala keluarga tentang siaran-siaran di radio Pekka FM, (2) Frekuensi mendengarkan, (3) siaran radio yang paling diminati/disukai, (4) manfaat yang diperoleh dari mendengarkan siaran-siaran radio Pekka FM, dan (5) perubahan yang terjadi pada perempuan kepala keluarga tersebut setelah mendengarkan siaran-sairan radio Pekka FM. Selanjutnya dilakukan tahapan pengungkapan makna yang lebih mendalam melalui interpretasi data secara lebih dalam menurut tradisi fenomenologis. 
Pengetahuan tentang siaran radio Pekka FM berdasar pada data yang diperoleh para perempuan kepala keluarga memberikan gambaran siaran / pogram siaran yang dipancarkan oleh Radio Pekka FM meliputi: kesehatan, hukum, kdrt, kb, talk show, iklan, hiburan (lagu-lagu), dan Program Pekka, seperti yang disajikan dalam tabel berikut:

Tabel 2

\section{Pengetahuan Tentang Siaran Radio Pekka FM}

\begin{tabular}{cc}
\hline Nama Informan & $\begin{array}{c}\text { Pengetahuan tentang Program yang } \\
\text { disiarkan Pekka FM }\end{array}$ \\
\hline Sumiati, Kartini, MurtiSari, Yanti, Mukmin, & Kesehatan \\
Rademah dan Wirati & Siaran tentang Pekka \\
Alemah, Asmunim Wiranti & Iklan \\
Mukmin, Rademah, Wiranti & Hukum \\
Sumiati, Kartini, & Berita KDRT \\
Sumiati. Rademah & Talk Show \\
Yanti, & Hiburan \\
Mukmin & Program KB \\
Yanti & \\
\hline
\end{tabular}

Sumber: Hasil Penelitian.

Dari 11 informan yang berhasil diwawancara, ada dua orang yang tidak memberikan jawabannya tentang program-program apa saja yang mereka kenali di Radio Pekka FM ini, yaitu: Ibu Suraih dan Ibu Rakdah. Dari delapan program yang dikenal oleh para perempuan kepala keluarga, program Kesehatan menempati urutan yang paling dikenali (6 informan mengenal program ini derngan baik). Di urutan ke 2 yang dikenal dengan baik oleh para perempuan kepala keluarga di Kabupaten Lombok Barat adalah siaran tentang Pekka Urutan ke dua adalah iklan, disusul dengan siaran iklan terutama iklan tentang KDRT, dimana ada 3 informan yang mengenal iklan ini dengan baik. Selanjutnya informan juga mengenal siaran tentang hukum dan KDRT. Selanjutnya adalah siaran tentang KB dan talk show.

Siaran Radio yang paling diminati, selain pengetahuan tentang program yang disiarkan melalui Radio Pekka FM dan intensitas para perempuan kepala keluarga mendengarkan siaran-siarannya, peneliti juga menanyakan tentang siaran-siaran radio yang disukai atau diminatinya. Berdasarkan data yang diperoleh tentang siaran radio yang diminati/ disukai oleh para informan, dapat dikategorikan 7 siaran yang disukai, yaitu: Siaran tentang reproduksi wanita, kesehatan remaja, siaran tentang kehamilan, KB, berita seputar Pekka, hiburan, dan iklan., seperti yang digambarkan dalam tabel berikut: 
Tabel 3

Siaran Radio yang paling Diminati

\begin{tabular}{cc}
\hline Nama Informan & $\begin{array}{c}\text { Siaran Radio yang paling } \\
\text { disukai/diminati }\end{array}$ \\
\hline Sumiati, Kartini, Yanti, Asmuni, Rademah, & Siaran tentang reproduksi wanita \\
Wiranti & \\
Sumiati, Kartini,Mukmin, Asmuni, Wiranti & Siaran tentang kehamilan \\
Murtisari, Yanti, Asmuni, Wiranti & Siaran tentang kesehatan (remaja) \\
Yanti, Rademah, Mukmin & Siaran tentang KB \\
Asmuni & Siaran tentang Pekka \\
Murtisari & Hiburan \\
Yanti & Iklan KDRT \\
& \\
\hline
\end{tabular}

Sumber: hasil penelitian

Merujuk pada table di atas, 11 orang informan yang ditanyai tentang program siaran yang paling diminati/disukai, ada dua orang informan yang menyatakan tidak ada program siaran yang diminatinya. Dari table yang diberikan, dapat terlihat bahwa 6 orang dari 11 informan yang menyukai siaran tentang reproduksi wanita; disusul kemudian dengan siaran tentang kehamilan yang diminati oleh 5 orang informan. 4 informan menyukai siaran tentang kesehatan remaja; 3 orang menyukai tentang siaran $\mathrm{KB}$, hanya 1 orang menyukai siaran tentang Pekka, 1 orang menyukai hiburan, dan 1 orang lainnya menyukai iklan KDRT.

Manfaat yang diperoleh dari siaran radio Pekka FM. Radio Pekka FM sudah berdiri sejak tahun 2008, program-program yang disiarkan oleh Radio Pekka FM sangat bervariatif, seperti yang sudah dirauiak sebelumnya bahwa ada 7 kategori program siaran yang disukai atau diminati oleh para perempuan kepala keluarga di Kabupaten Lombok Barat ini, yaitu: siaran tentang reproduksi wanita, kesehatan kehamilan, KB, berita Pekka, hiburan dan iklan KDRT, dan tentu saja masih banyak program lain yang disiarkan oleh radio Pekka FM, di antaranya: talk show (dialog interaktif), masalah hukum, masalah ekonomi, dan pernikahan di bawah umur. Semua program yang disiarkan oleh Radio Pekka FM tentu ada yang bernilai manfaat ada juga yang tidak memberikan manfaat.

Manfaat siaran radio Pekka FM yang didapatkan oleh para perempuan kepala keluarga di Kabupaten Lombok Barat sesuai dengan penuturan para informan dapat dikategorikan sebagai berikut: (a) jadi tahu tentang kesehatan, terutama kesehatan reproduksi wanita, (b) jadi tahu tentang kebersihan dan kesehatan lingkungan, (c) jadi tahu cara ber KB, (d) jadi tahu tentang kehamilan, (e) jadi bisa memberikan informasi kepada perempuan lainnya.

Kategorisasi tentang manfaat-manfaat siaran Radio Pekka dapat 
Chairiawaty

digambarkan dalam tabel berikut:

Tabel 4. Manfaat yang Diperoleh dari Siaran Radio Pekka FM

\begin{tabular}{|c|c|}
\hline Nama Informan & Manfaat Siaran yang Diperoleh \\
\hline $\begin{array}{c}\text { Suniati, Kartini, Alemah, Asmuni, Rademah, } \\
\text { Wiranti }\end{array}$ & $\begin{array}{l}\text { Jadi tahu tentang kesehatan, terutama } \\
\text { kesehatan reproduksi wanita, }\end{array}$ \\
\hline Rademah & $\begin{array}{l}\text { Jadi tahu tentang kebersihan dan } \\
\text { kesehatan lingkungan, }\end{array}$ \\
\hline Mukmin & Jadi tahu cara ber KB \\
\hline Alemah & Jadi tahu tentang kehamilan \\
\hline Yanti & $\begin{array}{l}\text { Jadi bisa memberikan informasi kepada } \\
\text { perempuan lainnya }\end{array}$ \\
\hline
\end{tabular}

Sumber: hasil penelitian

Tabel di atas menunjukkan kategorisasi tentang manfaat siaran radio yang dirasakan oleh para kelompok perempuan kepala keluarga dapat digambarkan bahwa: 6 orang informan merasakan manfaat dari siaran radio Pekka FM tersebut karena mereka menjadi tahu tentang kesehatan reproduksi wanita; 1 orang informan menjadi tahu tentang keberihan dan kesehatan lingkungan; 1 orang memperoleh manfaat menjadi tahu tentang ber KB; 1 orang menjadi tahu tentang masalah kehamilan; dan satu orang lagi menjadi tahu bagaimana berbagi informasi dengan perempuan lainnya. Dari 11 informan yang diwawancara, dua orang mengatakan tidak tahu tentang manfaat yang diperoleh, sedangkan satu lainnya mengungkapkan bahwa siaran-siaran radio Pekka FM banyak memberikan manfaat tanpa memberikan secara spesifik apa manfaatnya.

Setelah mengetahui manfaat yang diperoleh dari siaran-siaran Radio Pekka FM, maka terjadi perubahan dalam diri individu dan kelompok pendengar Pekka FM. Berdasarkan hasil penuturan dari para informan, diperoleh kategorisasi tentang perubahan-perubahan yang dirasakan oleh para perempuan kepala keluarga tersebut setelah mendengarkan siaran siaran radio Pekka FM, yaitu: (a) Lebih percaya diri, (b) lebih menjaga dan merawat diri, (c) Lebih berani untuk bicara.

Perubahan yang dirasakan oleh para perempuan kepala keluarga tersebut setelah mendengarkan siaran-siaran dari Radio Pekka FM tersebut, yaitu; dapat mengubah pola pikir dan mental para perempuan kepala keluarga, sehingga menjadi percaya diri, merawat tubuh, dan berani berbicara. Berikut kategorisasi yang didapatkan dari hasil penelitian, seperti dalam table berikut: 
Pemaknaan Perempuan Kepala Keluarga Tentang Pesan-Pesan Pada Radio Komunitas Pekka FM

Tabel 5. Perubahan yang Dirasakan setelah Mendengarkan Siaran-Siaran Radio Pekka FM

\begin{tabular}{cc}
\hline Nama Informan & Perubahan yang dirasakan \\
\hline Kartini, Murti Sari, Mukmin, Alemah, dan & Lebih percaya diri \\
Asmuni & \\
Sumiati, Kartini, Murtisari, Rademah & Lebih menjaga dam merawat tubuh \\
Yanti, Mukmin, Wiranti & Lebih berani untuk bicara \\
\hline
\end{tabular}

Sumber: hasil penelitian

Merujuk pada tabel dapat diperoleh gambaran sebagai berikut: 6 orang atau dapat dikatakan lebih dari sebagian besar informan menyatakan bahwa mereka menjadi lebih percaya diri setelah sering mendengarkan siaran-siaran dari Radio Pekka FM. 4 orang dari mereka atau sekitas $45 \%$ menyatakan adanya perubahan sikap dan perilaku pada diri mereka setelah sering mendengarkan siaran-siaran dari radio Pekka yaitu menjadi lebih peduli terhadap kesehatan mereka, mereka jadi lebih merawat diri. Sedangkan yang terakhir yaitu 3 dari 11 informan menyatakan setelah mereka mendengarkan siaran-siaran di Radio Pekka FM, mereka ingin menyampaikan informasi itu kepada perempuan lainnya, sehingga menjadikan mereka lebih berani untuk bicara.

Pembahasan mengenai pemaknaan perempuan kepala keluarga terhadap pesan-pesan pemberdayaan perempuan di Radio Pekka FM menggunakan pendekatan interpretif yang menekankan pada pemahaman artinya menemukan makna suatu peristiwa atau praktik sosial dengan interpretasi sehingga dapat ditemukan makna atau signifikansi tindakan, ada keanekaragaman kebudayaan yang luas berkenaan dengan cara kehidupan sosial dikonseptualisasi, dan perbedaan-perbedaan tersebut dengan sendirinya meningkatkan diversitas dunia sosial, praktik-praktik sosial dimanifestasikan oleh makna, tidak ada fakta kasar dalam ilmu sosial (Salviana, 2009).

Perbedaan budaya ada kemungkinan akan menyebabkan permasalahan komunikasi, hal ini wajar dan mesti dimaklumi, tidak menjadikan kita lebih agresif apalagi sampai bermusuhan (Muchtar, Koswara \& Setiaman, 2016). Dalam tradisi fenomenologi yang mengacu pada sifat-sifat suatu sistem perilaku yang dapat diamati yang memiliki kriteria beraturan dan tidak beraturan (Zuchowski, 2018) Nina Syam (2009: 165-166) mengungkapkan bahwa Fenomenologi merupakan studi tentang bagaimana seorang manusia mencari pengalaman di dunia. Ia melihat objek dan even dalam perspektif komunikator yang dalam praktek komunikasinya mengaitkan antara pemahaman dan nilai-nilai manusia dengan keberlanjutan yang dibangun secara sosial melalui komunikasi dengan orang lain (Alexandrescu et al., 2016). Pendekatan ini berangkat dari metode-metode kaum objektivis yang mengasumsikan bahwa kenyataan itu terlepas dari kesadaran prestasi manusia, dengan kata lain fenomenologi membuat pengalaman hidup yang aktual sebagai data dasar pengetahuan. 
Ada tiga prinsip dasar fenomenologi yang menargetkan pengalaman subyektif dari kehidupan sehari-hari individu, biasanya digunakan untuk memahami interpretasi dan makna dalam kaitannya dengan pengalaman hidup serta mempelajari dengan cermat guna menemukan makna yang lebih dalam dari pengalaman yang dialami dalam hal hubungan individu dengan ruang, waktu, dan sejarah pribadi, suatu pendekatan memiliki potensi untuk memberikan pemahaman fenomena yang lebih kaya - pengalaman subjektif dan bagaimana orang memahami mereka (Alfakhri, Harness, Nicholson, \& Harness, 2017), yaitu : 1) Pengetahuan ditemukan secara langsung dalam pengalaman sadar-kita akan mengetahui dunia ketika kita berhubungan dengannya, 2) makna benda terdiri atas kekuatan benda dalam kehidupan seseorang. Dengan kata lain, bagaimana anda berhubungan dengan benda menentukan maknanya bagi anda; 3) Bahasa merupakan kendaraan makna. Kita mengalami dunia melalui bahasa yang digunakan untuk mendefenisikan dan mengekspresikan dunia itu. Kita mengetahui kunci karena bahasa yang kita hubungkan dengannya: "menutup". "membuka" dan sebagainya (Deetz dalam Littlejohn, 2008:57).

Proses interpretasi yang secara umum bisa dikatakan sebagai tafsiran akan digunakan dalam penelitian untuk melihat kemungkinan pemahaman yang muncul melalui aspek visual dengan ketidaksadaran manusia (Siregar \& Ali, 2011). Sangatlah penting dalam sebuah tradisi fenomenologi, karena interpretasi merupakan sebuah proses untuk menentukan makna di dalam ujaran bahasa sebenarnya sama saja dengan makna yang ada dalam sistem lambang atau sistem tanda lainnya karena bahasa sesungguhnya juga merupakan suatu sistem lambang. Hanya bedanya makna dalam bahasa diwujudkan dalam lambang-lambang yang berupa satuan-satuan bahasa, yaitu kata/leksem, frase, kalimat, dan sebagainya (Chaer \& Muliastuti, 2014). Melalui pengalaman, interpretasi membentuk apa yang nyata bagi seseorang. Selain itu, interpretasi merupakan proses aktif pikiran dan tindakan kreatif dalam mengklarifikasi pengalaman pribadi. Interpretasi melibatkan maju mundur antara mengalami suatu kejadian atau situasi dan menentukan makna yang bergerak dari yang khusus ke yang umum dan kembali lagi ke yang khusus yang dikenal dengan istilah hermeneutic circle. Hermeneutika merupakan salah satu pendekatan yang digunakan untuk menganalisis suatu teks. Saat ini hermeneutika banyak digunakan dalam kajian teks hampir di segala bidang keilmuan, antara lain: filsafat, seni, sastra, sejarah, hukum, dan yang lainnya, tidak terkecuali dalam studi hukum Islam. Salah satu karakteristik hukum Islam adalah posisinya berada di wilayah idealisme dan positivism (Purkon, 2014). Kita membuat interpretasi akan sebuah kejadian atau pengalaman serta kemudian menguji interpretasi tersebut dan sekali lagi melihat dengan cermat pada detail kejadian yang merupakan sebuah proses berkelanjutan dalam memperbaiki makna kita.

Hasil penelitian melalui pengumpulan data di lapangan kemudian diproses 
dan diperoleh display data. Data kemudian direduksi sehingga diperoleh klasifikasi pemaknaan yang terdiri dari makna prosedural dan konseptual, dimana penanda wacana dianggap sebagai pembawa makna prosedural (Mohammadi, 2019) yang diberikan perempuan kepala keluarga mengenai pesan-pesan pemberdayaan dalam siaran-siaran di Radio Pekka FM. Pemaknaan pesan-pesan pemberdayaan melalui siaran-siaran Radio Pekka merupakan hasil interpretasi perempuan kepala keluarga setelah mengikuti atau mendengarkan siaran-siaran yang diberikan. Proses pemaknaan perempuan kepala keluarga terhadap pesan-pesan pemberdayaan yang disampaikan melalui siaran-siaran di radio Pekka meliputi lima hal yang saling berkaitan yaitu : (1) pengetahuan perempuan kepala keluarga tentang siaran-siaran di radio Pekka FM, (2) Frekuensi mendengarkan, (3) siaran radio yang paling diminati/disukai, (4) manfaat yang diperoleh dari mendengarkan siaran-siaran radio Pekka FM, dan (5) perubahan yang terjadi pada perempuan kepala keluarga tersebut setelah mendengarkansiaran-siaran Radio Pekka FM.

\section{Pengetahuan Perempuan Kepala Keluarga tentang Siaran-siaran di Radio Pekka FM}

Pertemuan rutin Kelompok Pekka, para perempuan kepala keluarga dibekali berbagai macam keterampilan dan pendidikan. Keterampilan tersebut meliputi keterampilan koperasi untuk modal usaha, dengan model simpan pinjam, program keaksaraan fungsional (Calistung), juga beberapa penyuluhan seperti penyuluhan tentang pernikahan dan perceraian, hukum, KDRT, dan kesehatan terutama kesehatan wanita. Ketika anggota Pekka semakin bertambah jumlahnya, dan pendamping lapang sudah mulai repot mengatur waktu pertemuan, maka untuk memberikan informasi kepada para perempuan keluarga lainnya yang sulit terjangkau, dipandu oleh Pemdamping Lapang yang mengajukan ijin untuk membangun Radio Komunitas. Perjuangan mereka memang tidaklah mudah, akan tetapi dengan ketekunan dan bantuan dari JRK, maka pada tahun 2008 berhasil mendirikan sebuah radio komunitas, meskipun peralatan yang dimiliki masih sangat sederhanam tetapi gaung Radio Komunitas Pekka FM sudah mulai bisa dirasakan untuk masyarakat sekitar.

Awalnya Radio Pekka FM ini berlokasi di Desa Mesanggok. Setelah beroperasi selama satu tahun, lokasi Radio Pekka FM dipindahkan ke rumah ketua kelompok Pekka Kecamatan Gerung, yaitu ibu Katsiroh, di dusun Batumulik. Bila pada awalnya, siaran hanya berlangsung sekitar 12 jam saja sehari, sekarang sudah 20 jam sehari, dengan penyiar yang diambil dari anggota Pekka sendiri setelah mereka mendapatkan pelatihan singkat. Berada di Frekuensi 107, 8 MHZ, penyiar akan membuka sapaan kepada para pemirsa dengan Bahasa Sasak: Sila Pirengan RK Peke a FM. Setelah itu penyiar akan memberikan berbagai macam program siaran.

Ada beberapa program yang disiarkan oleh Radio Komunitas Pekka. Di antara program-program yang disiarkan program yang dikenal baik oleh para perempuan kepala keluarga adalah: program Kesehatan, Berita tentang Pekka, 
Iklan KDRT, siaran tentang Hukum, siaran tentang KB dan Talk Show.

Acara kesehatan memang sangat dikenal baik oleh para perempuan kepala kelaurga ini terutama adalah kesehatan wanita, seperti tentang alat reproduksi. Para perempuan kepala keluarga di Kabupaten Lombok Barat memang bisa dikatakan kurang memperhatikan kesehatan, baik kesehatan fisik, lingkungan apalagi kesehatan reproduksi wanita.

Fasilitas di kecamatan Gerung, untuk sarana kebersihan lingkungan seperti MCK masih sangat langka, semua kegiatan mandi, mencuci, buang air dilakukan di sungai berbarengan dengan kuda atau kambing dan hewan lainnya. Apabila mereka memelihara hewan ternak, maka akan disatukan dengan tempat tinggal yang lantainya pun masih tanah. Oleh karena itu, siaran kesehatan merupakan acaranya yang paling mereka kenali, karena memang porsi jam siarannya lebih banyak daripada siaran lainnya. Siaran kesehatan yang paling mereka kenali adalah siaran kesehatan wanita.

Acara radio yang mereka kenali selain acara kesehatan adalah berita tentang Pekka, seperti misalnya jadwal tentang pertemuan rutin Serikat Pekka, program-program apa yang akan diselenggarakan di pertemuan rutin, apakah ada program tambahanm atau ada pertemuan luar biasa dal lain sebagainya. Di samping berita tentang Pekka, para perempuan kepala keluarga juga mengetahui adanya acara lain yang disiarkan melalui Radio Pekka FM, yaitu berita tentang KDRT berikut iklannya, siaran tentang Hukum, siaran tentang KB dan Talk Show.

Sesuai dengan fokus yang khas dari radio komunitas yaitu membuat audiens/khalayaknya sebagai protagonis (tokoh utama), melalui keterlibatan mereka dalam seluruh aspek manajemen, dan produksi programnya. Program juga menyajikan yang membantu mereka dalam pembangunan dan kemajuan sosial di komunitas. Radio Pekka FM dibangun berdasarkan kebutuhan para perempuan kepala keluarga yang ada di dusun Batumulik, agar bisa memberikan berbagai informasi yang diperlukan para perempuan kepala keluarga. Khususnya yang tidak bisa datang ke pertemuan kelompok Pekka, dan para perempuan atau masyarakat lainnya di sekitar kecamatan Gerung.

Pembangunan Radio Pekka FM sebagai saluran komunikasi massa. Sementara itu perempuan kepala keluarga dibangun oleh para perempuan tersebut, diperuntukkan utamanya bagi mereka, sehingga ketika program-program siarannya disusun, para perempuan kepala keluarga tersebutpun terlibat, melalui kader dan ketua kelompok. Bahkan penyiar pun diambil dari anggota Pekka sendiri. Sehingga konsep dari, oleb dan untuk mereka memang diterapkam dalam radio komunitas Pekka FM ini. Oleh karena itu pengetahuan para perempuan kepala keluarga di Dusun Batumulik Kecamatan Gerung terhadap programprogram yang disiarkan oleh radio Pekka bisa dikategorikan baik. 


\section{Siaran Radio yang Diminati}

Radio komunitas merupakan radio yang didirikan oleh komunitas tertentu, bersifat independen dan tidak komersial, dengan daya pancar rendah, luas jangkauan wilayah terbatas, serta untuk melayani kepentingan komunitasnya, selain itu radio komunitas harus memperlakukan pendengar sebagai subjek dan pesertanya terlibat dalam penyelenggaraannya (Fraser \& Estrada, Unesco, 2010:29).

Apa yang sudah dilakukan oleh Radio Komunitas Pekka FM dapat dikatakan sejalan dengan yang diungkapkan oleh Fraser dan Estrada tersebut. Tujuan utama didirikannya radio komunitas Pekka FM adalah untuk memberikan informasi seluas-luasnya kepada para anggota Serikat Pekka yaitu para perempuan kepala keluarga baik yang tercatat sebagai anggota biasa ataupun anggota luar biasa, sesuai dengan yang mereka butuhkan. Oleh karena itulah acara atau pun berita yang disiarkan oleh Radio Pekka FM merupakan acara yang disusun bersama oleh para perempuan kepala keluatga tersebut. Disinilah letak keunggulan radio komunitas yang memperlakukan pendengar sebagai subjek, sesuai dengan slogannya, yaitu: dari, oleh dan untuk mereka.

Dari sejumlah program siaran yang disiarkan oleh Radio Pekka FM, ada 6 program yang diminiati oleh para pendengar, dengan tingkat kesukaan berbeda. 6 orang dari 11 informan yang menyukai siaran tentang reproduksi wanita; disusul dengan siaran tentang kehamilan yang diminati oleh 5 orang informan. 4 informan menyukai siaran tentang kesehatan remaja; 3 orang menyukai tentang siaran $\mathrm{KB}$, hanya 1 orang menyukai siaran tentang Pekka, 1 orang menyukai hiburan, dan 1 orang lainnya menyukai iklan KDRT.

Para perempuan kepala keluarga yang menjadi anggota Serikat Pekka di dusun Batumulik rata-rata saat ini berusia 35 tahun bahkan kurang, adapun anggota yang sudah berusia lebih dari 50 tahun relatif sangat sedikit. Mengingat usianya yang dapat dikatakan masih produktif, para perempuan kepala keluarga tersebut masih berharap untuk bisa berumah tangga lagi. Oleh karena itulah mereka sangat menyukai siaran tentang kesehatan reproduksi wanita, di samping mereka sendiri merasa wajib untuk merawat kesehatan reproduksi mereka agar terhindar dari berbagai macam penyakit. Begitupun dengan siaran tentang kehamilan, mereka merasa penting untuk mendengarkan siaran ini, dengan alasan bahwa bila mereka bisa menikah lagi dan hamil mereka bisa mempersiapkannya, ataupun mereka bisa memberikan informasi kepada para ibu lainnya yang sedang hamil.

Ketika menikah para perempuan kepala keluarga tersebut masih berusia sangat belia yaitu 15 atau 17 tahun. Saat menginjak usia 35 di antara mereka ada yang sudah memiliki anak usia remaja. Oleh karena itulah para perempuan kepala keluarga sangat menyukai acara kesehatan remaja yang disiarkan oleh Radio Pekka FM, karena dengan seringnya mereka mendengarkan informasi tentang kesehatan 
remaja, maka mereka bisa memberikan informasi itu kepada anak-anak remaja mereka. Program-program siaran ini sangat sesuai dengan tujuan komunikasi secara umum yaitu untuk memberikan informasi, dan untuk mendidik.

Selain siaran tentang kesehatan remaja, para perempuan kepala keluarga di dusun Batumulik juga meminta siaran seputar kegiatan Pekka atau informasiimformasi lain tentang Pekka. Dengan adanya siaran ini mereka semakin tahu tentang kegiatan-kegiatan Pekka, sehingga mereka bisa berbagi informasi dengan anggota Pekka lainnya. Program ini sejalan dengan tujuan komunikasi untuk meyakinkan. Sedangkan tujuan komunikasi yang keempat yaitu untuk menghibur tercermin dalam siaran hiburan Hiburan terutama lagu-lagu daerah dan cerita daerah, dan tujuan komunikasi untuk membujuk tercermin dalam iklan-iklan terutama iklan KDRT yang dipancarkan oleh Radio Pekka FM juga merupakan acara yang diminati oleh para perempuan keluarga di Kecamatan Gerung dan Labuapi.

\section{Manfaat yang Diperoleh dari Siaran Radio Pekka FM}

Keberadaan media komunitas, khususnya radio siaran, di beberapa negara berkembang sudah diakui memiliki nilai manfaat yang cukup tinggi. The National Community Radio Forum (NCRF) is a national, membership-based association of community radio stations and support service organisations. Radio station members are independent nonprofit community based organisations, onmed and run by diverse local communities who actively participate in the development of programming activities for sustainable non-discriminatory local development (National et al., n.d.).

Sebuah forum radio komunitas yang sudah memiliki 54 anggota stasiun radio komunitas di dunia, mengemukakan manfaat dari radio komunitas, sebagai berikut: 1) Radio komunitas memperkuat partisipasi sebuah komunitas untuk membuka pintu perubahan kehidupan komunitas tersebut 2) Radio komunitas bisa melayani informasi di segala sektor kehidupan komunitas 3) Radio komunitas dapat mempromosikan dan merefleksikan budaya, karakter dan identitas komunitasnya. 4) Radio komunitas dapat meningkatkan akses untuk penyebaran informasi secara lisan 5) Radio komunitas dapat memberikan tanggung jawab sosial atas kebutuhan komunitasnya 6) Radio komunitas dapat berperan penting sebagai pemberi kekuatan bagi kaum yang terpinggirkan.

Radio Komunitas Pekka FM yang merupakan media komunitas para perempuan kepala keluarga di Dusun Batumulik, Kabupaten Lombok Barat sejak didirikannya pada tahun 2008 telah memberikan mamfaat bagi komunitasnya, yaitu para perempuan kepala keluarga. Manfaat yang dirasakan oleh para perempuan kepala keluarga sesuai yang mereka ungkapkan adalah : (a) mereka menjadi tahu tentang kesehatan reproduksi wanita; (b) menjadi tahu tentang keberihan dan kesehatan lingkungan; (c) menjadi tahu tentang ber KB; (d) menjadi tahu tentang masalah kehamilan; dan (e) menjadi tahu bagaimana berbagi 
informasi dengan perempuan lainnya.

Kelima manfaat Radio komunitas Pekka FM yang dirasakan oleh para perempuan kepala keluarga di Kabupaten Lombok Barat tersebut sejalan dengan manfaat radio komunitas berdasarkan kajian dari The National Community Radio Forum (NCRF). Manfaat yang ditemukan oleh NCRF salah satunya adalah bahwa Radio komunitas bisa melayani informasi di segala sektor kehidupan komunitas. Begitu pun informasi yang diperoleh oleh para perempuan kepala keluarga ini adalah informasi tentang: kesehatan reproduksi, informasi tentang kebersihan dan kesehatan lingkungan, informasi tentang KB dan kehamilan. Dengan informasi-informasi yang disiarkan oleh radio Pekka FM tersebut maka terjadi perubahan secara kognitif pada para perempuan kepala keluarga tersebut, mereka menjadi lebih tahu tentang kelima hal tersebut.

Perubahan kognisi pada perempuan kepala keluarga tersebut juga melahirkan sikap positif pada perempuan tersebut, mereka menjadi lebih percaya diri, lebih sadar, dan lebih perduli, dan tidak terbatas hanya pada diri mereka sendiri, tetapi juga untuk para perempuan lainnya. Sebagaimana yang diungkapkan oleh para perempuan tersebut bahwa dengan bertambahnya pengetahuan mereka tentang kesehatan reproduksi, kebersihan lingkungan, masalah KB dan kehamilan, mereka menjadi bisa berbagi informasi kepada perempuan lainnya.

Perubahan prilaku ini sangat sesuai dengan manfaat radio komunitas yang telah dikaji oleh NCRF yaitu bahwa radio komunitas dapat meningkatkan akses untuk penyebaran informasi secara lisan. Selain itu menyebaran informasi yang dibutuhkan merupakan manfaat lain dari radio komunitas dalam memberikan tanggung jawab sosial atas kebutuhan komunitasnya, dan inilah peran penting radio komunitas dalam pembangunan masyarakat (pemberdayaan masyarakat) yaitu dapat memberikan kekuatan bagi kaum yang terpinggirkan.

\section{Perubahan pada Perempuan Kepala Keluarga setelah Mendengarkan Siaran Radio Pekka FM}

Perubahan-perubahan yang terjadi pada para perempuan kepala keluarga di Kabupaten Lombok Barat setelah sering mendengarkan siaran-siaran yang dipancarkan oleh Radio Pekka FM merupakan hasil pemaknaan mereka terhadap pesan-pesan atau isi siarannya berdasarkan pemahaman individu dan sosialnya. Isi media ditafsirkan dalam komunitas menurut makna yang dikembangkan secara sosial dalam kelompok tersebut dan oleh individu yang dipengaruhi oleh rekanrekan mereka. . Dalam mengkaji tentang perubahan-perubahan yang terjadi pada para perempuan kepala keluarga di Kabupaten Lombok Barat setelah mendengarkan siaran-siaran pada Radio Pekka FM, teori ini dijadikan landasan berpikir bagi penulis mengingat bahwa pesan-pesan, program-program, atau isi 
siaran yang dibawakan pada Radio Komunitas Pekka FM akan dimaknai secara komunal oleh komunitas Pekka, dan makna yang diberikan oleh individu pun akan diwarnai oleh pemaknaan sosial mereka.

Perubahan-perubahan yang dirasakan oleh para perempuan kepala keluarga tersebut setelah mendengarkan siaran siaran radio Pekka FM, yaitu: (a) lebih percaya diri, (b) lebih menjaga dan merawat diri, (c) Lebih berani untuk bicara. Perubahan-perubahan yang terjadi pada para perempuan kepala keluarga ini, merupakan tindakan mereka sebagai hasil pemahamannya secara individu yang sudah sesuai dengan asumsi mengenai tindakan manusia yang dipahami Schutz sebagai realitas yang didasarkan pada pemahaman atau makna terhadap tindakan tersebut.

Shults mendefinisikan tindakan seseorang yang bisa memengaruhi perilaku organisasi, yang pada akhirnya tercermin dalam kinerja organisasi (Lenka, Parida, Ronnberg, \& Wincen, 2017) sebagai prilaku yang bermakna subjektif yang merujuk pada proses implisit, intuitif dan emosional yang terkait dengan konsep. Makna ini mengandung pengetahuan sosial dan budaya yang tersirat, memperoleh respons emosional spesifik dan membatasi pilihan perilaku orang (Wolf, Schroeder, \& Berlin, 2019). Pemaknaan para perempuan secara individu kemudian akan berkembang menjadi pemaknaan sosial yang terbentuk melalui kegiatan interaksi yang dilakukan mereka dalam kegiatan-kegiatan mereka di Serikat Pekka. Makna ini menjadi makna intersubjektif yang pada gilirannya menjadi konstruksi sosial konstruksi sosial merupakan sosiologi pengetahuan maka implikasinya harus menekuni pengetahuan yang ada dalam masyarakat dan sekaligus proses-proses yang membuat setiap perangkat pengetahuan yang ditetapkan sebagai kenyataan (Manuaba, 2008) kepala keluarga di Dusun Batumulik Lombok.

Pemaknaan atau konstruksi sosial perempuan terhadap pesan-pesan Radio Pekka FM menggambarkan bahwa pemaknaan tersebut bukan merupakan persitiwa yang instan, akan tetapi melibatkan proses yang terus menerus dan berkelanjutan. Hasil penelitian mendeskripsikan bahwa para perempuan kepala keluarga di dusun Batumulik Kabupaten Lombok Barat pada awalnya hanya melakukan pemaknaan pada pesan-pesan radio Pekka FM sesuai dengan pengetahuan yang dimiliki mereka. Setelah itu pemaknaan perempuan tersebut mengalami perubahan setelah aktif mendengarkan siaran-siarannya atu dengan kata lain frekuensi mendengarkan mereka menjadi semakin sering. Dari seringnya mereka mendengarkan siaran-siaran Radio Pekka tersebut mereka bisa memperoleh manfaat-manfaatnya sebagimana telah diuraikan sebelumnya.

Internalisasi yang bersifat konsisten menunjukkan keadaan psikologis kritis seperti pengetahuan, kebermaknaan, dan tanggung jawab pribadi berdasarkan persepsi mereka terhadap desain aktivitasnya (Xiong \& King, 2019). Pesan-pesan atau konstruksi sosial yang membutuhkan kolaborasi komunitas aktor untuk menghasilkan dan mengkonsumsinya dengan cara tertentu (Venugopal, 2018) para 
perempuan kepala keluarga terhadap pesan-pesan yang disampaikan pasa siaransiaran Radio Pekka FM yang membuat para perempuan tersebut mengalami perubahan seperti yang mereka ungkapkan, yaitu: di Serikat Pekka ini yang dipahami sebagai makna transformatif terjadi dalam proses yang panjang melalui kegiatan komunikasi. Komunikasi dilakukan di antara pelaku pemberdayaan yaitu (a) mereka menjadi tahu tentang kesehatan reproduksi wanita; (b) menjadi tahu tentang keberihan dan kesehatan lingkungan; (c) menjadi tahu tentang ber KB; (d) menjadi tahu tentang masalah kehamilan; dan (e) menjadi tahu bagaimana berbagi informasi dengan perempuan lainnya. Makna yang diberikan oleh para perempuan kepalan keluarga di Dusun Batumulik oleh peneliti dimaknai sebagai Makna Perubahan.

Keberhasilan penyampaian pesan sehingga menjadi bermakna bagi perempuan kepala keluarga tersebut tidak terlepas dari strategi komunikasi yang dilakukan oleh Radio Pekka. Strategi komunikasi merupakan suatu langkah strategis sehingga dilakukan perencanaan dengan memperhatikan khalayak, pesan, metode, media, dan komunikator. Hal ini juga merupakan sebuah pendekatan secara keseluruhan yang berkaitan dengan pelaksanaan gagasan, perencanaan dan eksekusi sebuah aktivitas dalam kurun waktu tertentu (Sudarman, 2018).

Adapun model pemaknaan para perempuan kepala keluarga Serikat Pekka di Kabupaten Lombok Barat, dapat digambarkan dalam model berikut:

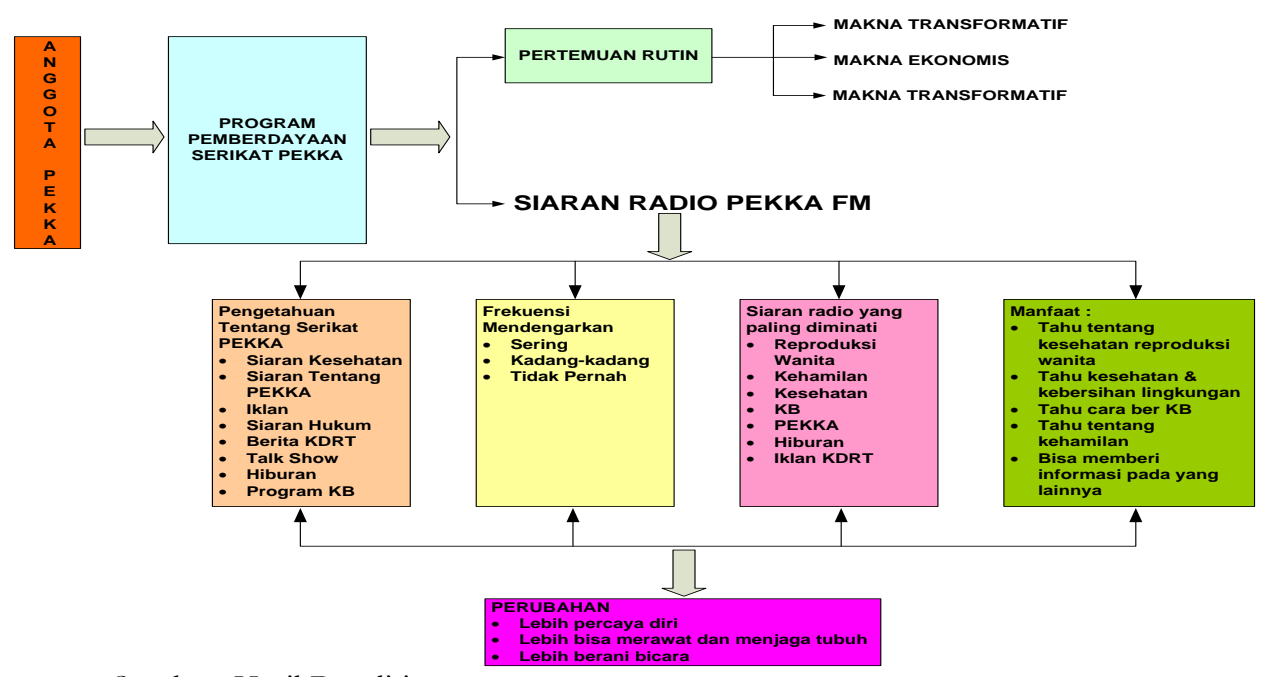

Sumber: Hasil Penelitian

Gambar 1. Model Pemaknaan Tentang Pesan-pesan Radio PEKKA FM 


\section{PENUTUP}

Penelitian ini menekankan pada sebuah pemahaman, artinya menemukan makna suatu peristiwa; dan metode fenomenologi yang merupakan studi tentang bagaimana seorang manusia mencari pengalaman di dunia dengan memaknai sebuah peristiwa dan objek yang dialaminya, dengan mengaitkan antara pemahaman dan nilai-nilai manusia dengan keberlanjutan yang dibangun secara sosial melalui komunikasi dengan orang lain.

Hasil penelitian tentang pemaknaan perempuan kepala keluarga terhadap pesan-pesan di Radio Pekka FM menunjukkan bahwa, pengetahuan para perempuan kepala keluarga di Dusun Batumulik terhadap programprogram yang disiarkan oleh radio Pekka FM ini bisa dikategorikan baik, dikarenakan sebagai saluran komunikasasi massa para perempuan kepala keluarga, Radio Pekka FM diperuntukkan utamanya bagi mereka, sehingga ketika program-program siarannya disusun, para perempuan kepala keluarga tersebutpun terlibat, melalui kader dan ketua kelompok, bahkan penyiar pun diambil dari anggota Pekka sendiri. Sehingga konsep dari, oleb dan untuk mereka memang diterapkan dalam radio komunitas Pekka FM ini.

Program-program siaran yang diberikan di Radio Pekka FM sangat sesuai dengan tujuan komunikasi secara umum yaitu untuk memberikan informasi, dan untuk mendidik. Selain itu siaran-siaran yang diberikan disesuaikan dengan kebutuhan para perempuan kepala keluarga. Siaran yang banyak diminati adalah tentang kesehatan remaja, kegiatan Pekka atau informasi-informasi lain tentang Pekka. Dengan adanya siaran ini mereka semakin tahu tentang kegiatan-kegiatan Pekka, sehingga mereka bisa berbagi informasi dengan anggota Pekka lainnya. Program ini sejalan dengan tujuan komunikasi untuk meyakinkan. Sedangkan tujuan komunikasi lainnya yaitu untuk menghibur, tercermin dalam siaran hiburan-hiburan terutama lagu-lagu daerah dan cerita daerah, dan tujuan komunikasi untuk membujuk tercermin dalam iklan-iklan terutama iklan KDRT yang dipancarkan oleh Radio Pekka FM juga merupakan acara yang diminati oleh para perempuan keluarga dusun Batumulik.

Radio Komunitas Pekka FM telah banyak memberikan manfaat bagi para perempuan kepala keluarga di dusun Batumulik. Manfaat yang dirasakan oleh para perempuan kepala keluarga adalah : (a) mereka menjadi tahu tentang kesehatan reproduksi wanita; (b) menjadi tahu tentang keberihan dan kesehatan lingkungan; (c) menjadi tahu tentang ber-KB; (d) menjadi tahu tentang masalah kehamilan; dan (e) menjadi tahu bagaimana berbagi informasi dengan perempuan lainnya.

Perubahan-perubahan yang dirasakan oleh para perempuan kepala keluarga tersebut setelah mendengarkan siaran-siaran radio Pekka FM, yaitu: (a) lebih percaya diri, (b) lebih menjaga dan merawat diri, (c) Lebih berani untuk bicara. Perubahan-perubahan yang terjadi pada para perempuan kepala keluarga ini, 
merupakan tindakan mereka sebagai hasil pemahamannya secara individu yang sudah sesuai dengan asumsi mengenai tindakan manusia yang dipahami sebagai realitas yang didasarkan pada pemahaman atau makna terhadap tindakan tersebut.

Pemaknaan perempuan terhadap terpaan pesan tersebut bukan merupakan peristiwa yang instan, akan tetapi melibatkan proses yang terus menerus dan berkelanjutan. Pemaknaan perempuan tersebut mengalami perubahan setelah aktif mendengarkan pesan-pesan media. Makna yang diberikan oleh para perempuan kepalan keluarga dimaknai sebagai makna perubahan.

\section{DAFTAR PUSTAKA}

Alexandrescu, F. M., Pizzol, L., Zabeo, A., Rizzo, E., Giubilato, E., \& Critto, A. (2018). Identifying Sustainability Communicators in Urban Regeneration : Integrating Individual and Relational Attributes. Journal of Cleaner Production, 173(Pebruari), 278-291. https://doi.org/10.1016/j.jclepro.2016.09.076

Alfakhri, D., Harness, D., Nicholson, J., \& Harness, T. (2018). The Role of Aesthetics and Design in Hotelscape: A Phenomenological Investigation Of Cosmopolitan Consumers. Journal of Business Research, 85(April), 523-531. https://doi.org/10.1016/j.jbusres.2017.10.031

Budiman, A., (2014). Penataan Lembaga Penyiaran di Indonesia. Jurnal Politica, 5(1),

https://jurnal.dpr.go.id/index.php/politica/issue/view/104/show'Toc

Chaer, A., \& Muliastuti, L. (2014). Semantik Bahasa Indonesia; Makna dan Semantik. 1(401.43) 1-39.

Fraser, C., and Estrada, S.R. (2002). Community Radio for Change and Development, dalam Development 45 (4): 69-73. DOI: 10.1057/palgrave.development.1110408

Lenka, S., Parida, V., Rönnberg, D., \& Wincent, J. (2018). Exploring the Microfoundations of Servitization: How Individual Actions Overcome Organizational Resistance. Journal of Business Research, 88 (November), 328336. https://doi.org/10.1016/j.jbusres.2017.11.021

Littlejohn, S.W. (2005) Theories of Human Communication, Thomson Learning Inch., Wadswordh, Belmont, USA.

Manuaba, I. B. P. (2008). Understanding The Theory of Social Construction. IJJS, 21(3), 221-230.

Mohammadi, A. N. (2019). Science Direct Meaning Potentials and Discourse Markers : The Case of Focus Management Markers in Persian. Lingua.

Moyo, R., \& Salawu, A. (2019). A Survey of Communication Media Preferred By Smallholder Farmers in The Gweru District of Zimbabwe. Journal of Rural Studies, 66(August), 112-118. https://doi.org/10.1016/j.jrurstud.2018.12.013

Muchtar, K., Koswara, I., \& Setiaman, A. (2016). Komunikasi Antar Budaya 
dalam Perspektif Antropologi. Jurnal Manajemen Komunikasi, 1(1), 113-124. DOI: $10.24198 /$ jmk.v1i1.10064

Purkon, A. (2014). Pendekatan Hermeneutika dalam Kajian Hukum Islam. AHKAM: Jurnal Ilmu Syariah, 13(2), 183-192. DOI: 10.15408/ajis.v13i2.930

Rachmiatie, A. (2005). Keberadaan Radio Komunitas sebagai Eskalasi Demokratisasi Komunikasi pada Komunitas Pedesaan di Jawa Barat. Mediator: Jurnal Komunikasi, 6(2), 215-226. DOI: https://doi.org/10.29313/mediator.v6i2.1190

Salviana, V. (2009). Pendekatan Interpretif dalam Ilmu-Ilmu Sosial. SALAM: Jurnal Ilmu-Ilmu Sosial, 1-12. http://ejournal.umm.ac.id/index.php/salam/issue/view/57/showToc

Saugi, W., \& Sumarno, S. (2015). Pemberdayaan Perempuan Melalui Pelatihan

Pengolahan Bahan Pangan Lokal. Jurnal Pendidikan dan Pemberdayaan Masyarakat, 2(2), 226. DOI: 10.21831/jppm.v2i2.6361

Siregar, A., \& Ali, H. (2011). Kontribusi Teori Interpretasi Psikoanalisis dan Hermeneutik Terhadap Proses Analisis/Pengkajian Film. Jurnal Sosioteknologi, 10(23), 1077-1092.

http://journals.itb.ac.id/index.php/sostek/issue/view/152.

Sudarman, A. (2018). Strategi Komunikasi untuk Meningkatkan Kesadaran Masyarakat dalam Membayar Zakat Maal. Communicatus: Jurnal Ilmu Komunikasi, 2(1), 38-60. DOI :10.15575/cjik.v2i1.5056

Sujata, M., Khor, K. S., Ramayah, T., \& Teoh, A. P. (2019). The Role of Social Media on Recycling Behaviour. Journal Sustainable Production and Consumption, 20, 365-374. https://doi.org/10.1016/j.spc.2019.08.005

Susanti, E, (2015). Komunikasi Partisipatif dalam Program Pemberdayaan Perempuan Kepala Keluarga (Kasus di Desa Dayah Tanoh Kecamatan Mutiara Timur Kabupaten Pidie Provinsi Aceh. Jurnal Agribisnis Terpadu, 8(2), 44-53. DOI: http://dx.doi.org/10.33512/jat.v8i2.1301

Syam, N. W. (2009). Sosiologi Komunikasi. Bandung: Penerbit Humaniora.

Venugopal, R. (2018). Ineptitude , Ignorance, or Intent : The Social Construction of Failure in Development. World Development, 106, 238-247. https://doi.org/10.1016/j.worlddev.2018.01.013

Wolf, I., Schröder, T., \& Berlin, F. U. (2019). Connotative Meanings of Sustainable Mobility: A Segmentation Approach Using Cultural Sentiments. Transportation Research Part A, 126(May), 259-280. https://doi.org/10.1016/j.tra.2019.06.002

Xiong, L., \& King, C. (2019). Journal of Hospitality and Tourism Management Aligning Employees' Attitudes and Behavior With Hospitality Brands : The Role of Employee Brand Internalization. Journal of Hospitality and Tourism Management, 40(June), 67-76. https://doi.org/10.1016/j.jhtm.2019.06.006 Yang, S., Fan, Y., Deng, W., \& Cheng, L. (2017). Do Built Environment Effects 
Pemaknaan Perempuan Kepala Keluarga Tentang Pesan-Pesan Pada Radio Komunitas Pekka FM on Travel Behavior Differ Between Household Members? A Case Study of Nanjing , China. Transport Policy, (June), 1-11. https://doi.org/10.1016/j.tranpol.2017.12.006

Zuchowski, L. C. (2018). Complexity as a Contrast Between Dynamics and Phenomenology. Studies in History and Philosopby of Modern Physics, (2017), 114. https://doi.org/10.1016/j.shpsb.2017.12.003 